\title{
Making The Animals on The Plate Visible: Anglophone Celebrity Chef \\ Cookbooks Ranked by Sentient Animal Deaths
}

Andy Lamey and Ike Sharpless

\section{Introduction}

Recent decades have witnessed the rise of chefs to a position of cultural prominence. Figures such as Jamie Oliver, Emeril Lagasse, Gordon Ramsey and Nigella Lawson have become international "brands." Television shows they host attract significant ratings and cookbooks published under their names are among the best-selling works of non-fiction in their respective countries (BARB 2017; BBC News 2010; Salkin 2013). The media treats television chefs as celebrities, documenting their romantic attachments and breakups and speculating about the size of their fortunes (e.g. Weatherby 2016; Complex 2012). These chefs are also viewed as authorities on culinary matters, to the point that members of the general public frequently cite them as sources of their own food knowledge (Caraher et al. 2000). Television chefs thus have a high "dietary credibility": rightly or wrongly, their views are granted substantial weight in public discussion of food issues (Penders 2012 1; Lane and Fisher 2015, Bagnoli et al 2016).

The rise of the chef as celebrity has coincided with increased consciousness of ethical issues pertaining to food, particularly as they concern animals. Recent legislative changes in the United States, the United Kingdom and other countries have outlawed such practices as the confinement of layer hens and the use of sow crates (ASPCA 2017; Druce and Lymbery 2006). Similarly, veal, fois gras and other foods perceived as involving especially painful production practices have become subjects not only of increased regulation but municipal, and in some cases national, bans (Dixler 2015; HSI 2015). Set against this backdrop, and whether they intend it 
or not, celebrity chefs' food choices and public meal recommendations are ethically significant.

It is likely that such chefs influence the cooking choices of the general public, although the precise nature of this influence is difficult to quantify. But directly influencing the public's food choices is not the only way in which celebrity chefs' food choices can be morally important. Regardless of how their audiences respond, the chefs' choices themselves send a message regarding what practices are acceptable when it comes to food and animals. To date, however, attention to the ethical messages of celebrity chefs has lagged behind the comparable work devoted to their stances regarding nutrition, health and other issues. ${ }^{1}$

We sought to correct this oversight by examining one ethical issue related to food: the number of animal deaths required to follow a television chef's culinary recommendations. We ranked cookbooks by celebrity chefs according to the minimum number of sentient animals that must be killed to make their recipes. On our stipulative definition, celebrity chefs are those with their own television show on a national network in the United States, the United Kingdom, Canada or Australia. ${ }^{2}$ Thirty cookbooks by 26 such chefs were categorized according to the total number of cows, pigs, chicken, fish and other species they included as ingredients. We determined the number of animals killed by counting the total weight of particular meats used in each book. The number of cows a given book

\footnotetext{
${ }^{1}$ Scholars have examined how celebrity chefs transfer "meanings and values" to businesses through celebrity endorsements (Halonen-Knight and Hurmerinta 1992); how they bestow class status on consumers who eat their food (Hyman 2008, Powell and Prasad 2010); how gender roles confine their public personas and cookbook narratives (Scholes 2011; Herkes and Redden 2014, Matwick and Matwick 2017); and how chefs often depict meat eating in a manner that promotes political doctrines such as nationalism and human superiority over nature (Buscemi 2016). We have been unable to find any scholarly analyses of the number of animal deaths recommended by celebrity chefs' cookbooks.

${ }^{2}$ Padma Lakshmi a self described "food expert: rather a professional chef (Padmalakshmi.com2017: 1). We use the term "celebrity chef" broadly to also include Lakshmi.
} 
required, for example, was determined by the overall amount of beef its recipes called for, the total number of pigs by the overall amount of pork, and so on. The number of carcasses was then divided by the number of non-dessert recipes to generate an average number of animal deaths per recipe for each book. We refer to the average number of deaths per non-dessert recipe in a given book as its animal harm footprint. In what follows, we outline the ethical rationale for our project and its methodology before presenting a ranked table of 30 cookbooks by celebrity chefs.

This method generated several interesting findings. The first concerns the wide variation in animal fatalities among cookbooks. The chef with the highest fatality rate killed an average of 5.25 animals per recipe, while the omnivorous chef with the lowest fatality rate killed an average of 0.19 per recipe. Clearly, not all approaches to meat eating are equal when it comes to their animal mortality rate. The prime determinant of a chef's place in the index was the number of small animals his or her recipes required. Whether a chef cooked in the style of a particular cuisine (Italian, French, Mexican etc.), by contrast, had no discernible influence on his or her ranking. We also found that certain types of meat generated high mortality counts because animals have limited amounts of certain organs or cuts of meat on their bodies. This includes specialty cuts such as the pork tenderloin on a pig and the flank steak on a cow (Holland et al. 2014).

After presenting our index, we use it to analyze and interpret how different chefs present themselves—as either especially sensitive or insensitive to ethical issues involving animals and food-and note cases where these presentations do or do not match their index ranking. Finally, we outline how two prominent chefs on our 
index, Hugh Fearnley-Whittingstall and Yotam Ottolenghi, provide potential models of approaches to cooking with significantly reduced harm footprints.

\section{An Animal-protection Rationale for Counting Sentient Food Animal Deaths}

Our project combines an empirical method with an ethical rationale. Because of its interdisciplinary nature it will be helpful to clarify from the beginning the ethical framework that has motivated us to count sentient animal deaths, as we think that doing so has broad appeal. That framework is one shaped in part by the philosophical literature on animal protection, our preferred term for what is often termed "animal rights."

Ethical frameworks based on animal welfare have traditionally been concerned with minimizing the suffering animals experience in the course of their usage by human beings (Gregory 1998). Views that go beyond this, as by for example challenging whether cosmetic testing or some other widely accepted usage is morally acceptable are often labelled animal-rights views. This label is potentially misleading, insofar as the question of whether animals warrant greater moral respect than welfare-based accounts have traditionally accorded them is distinct from the question of whether they have rights. Thus while Regan (1983) influentially defended a theory that goes beyond welfare by endorsing animal rights Singer (1990) is also a prominent proponent of extending greater moral standing to animals, but in a utilitarian manner that makes no appeal to the notion of rights. Regan and Singer's theories together are best identified not as theories of animal rights but of animal protection. Although they differ in many details, they

\footnotetext{
3 "In part" because we, the two authors, have overlapping but distinct views on animal ethics. In addition to the interest-based view of animal ethics outlined below, we get some of our ethical motivation from approaches influenced by Aristotelian virtue ethics and the capabilities approach (Nussbaum 2006) as well as biosemiotics, umwelt theory (Uexküll 1934 [2013]; Hoffmeyer 2008) and a wide range of other sources.
} 
both attribute to animals moral entitlements more robust than those found in traditional theories of animal welfare.

Our framework is an animal protection view in this broad sense. More specifically, it goes beyond a traditional animal-welfare framework by viewing killing as an event that can harm sentient animals and so requires justification, even when it is done painlessly. Sentient beings are here understood as those that are conscious and which have the capacity to experience pleasure and pain. Such creatures have a welfare-interest in continued existence that is distinct from their interest in avoiding suffering.

The philosophical argument for this view that has most motivated our project is McMahan's interest-based account (2002). It grants moral weight to the degree of psychological unity a creature has across time. As McMahan outlines the notion of psychological unity, the degree to which it is sustained through time in an individual's life "is a function of the proportion of the mental life that is sustained over that period, the richness or density of that mental life, and the degree of internal reference among the various earlier and later mental states" (McMahan 2002: 74-5). Fear and hunger are examples of mental states that can be sustained across time. Examples of later mental states that refer to earlier ones include memories and actions that fulfill desires formed much earlier. The greater the overall number of sustaining or interactive mental states, the greater the richness and density of a creature's mental life as a whole, and the greater the welfareinterest a creature has in its continued existence.

On this approach, the greater richness and density of the mental lives of selfconscious persons grants us a higher standing than sentient animals. The death of self- conscious beings such as a normal adult human matters more because death is 
a much greater loss for us. But death is nevertheless a loss for sentient animals, in a way that it is not for a plant. Insofar as our actions may end an animal's life it requires justification, albeit less stringent justification than would killing a person.

For present purposes we are less concerned to identify the precise threshold of justification required to kill an animal than we are simply to suggest that the act of killing animals is morally significant enough to warrant counting. To motivate this view, consider cases in which an animal is made to experience some displeasure for the sake of a longer life (McMahan 2002). Suppose, for example, that a dog has a condition which, while it causes no pain, will significantly shorten the animal's life. It seems consistent with widely held views about animals to think that if it were possible to give the dog a shot that would restore it to full health, all else being equal, it would be morally right to do so (cf McMahan 2008).

If that is the case, however, it suggests that the animal's life has value independent of the value of not causing it to suffer. In the scenario we are causing the animal pain in order to extend its life. This is hard to justify if suffering is the only morally significant animal trait. To make an animal suffer in the name of longevity is to presuppose that the animal's life is also morally valuable. To say this is of course not to say anything about how morally significant animal lives are relative to human ones. But insofar as animal lives matter morally-if they have moral standing at all—this suggests that there can be value in tracking the animal fatalities that our eating choices cause or endorse.

Our project is grounded in a concern for the harm death causes to food animals, but this is not the only reason to track their deaths. Doing so can also arguably be justified on animal welfare grounds. This second rationale appeals to the value of minimizing animal suffering as distinct from killing. Food animals occupy an "out 
of sight, out of mind" status, a status compounded by the urban consumer's alienation from animal husbandry practices. Chickens are the most widely consumed land animal, yet when people are asked to think of a bird they do not think of chickens, and they exhibit surprise when shown pictures of chickens roosting on tree branches or otherwise behaving like other birds. This is arguably an artifact of food animals' commodity status and gradual disappearance from modernity (Berger 1980), which renders them "devoid of authenticity as a real animal with an evolutionary history and phylogenetic context" (Marino 2017). Psychologically, even cognitively and neurologically, there are many possible reasons why we do not like to think about the bloody process by which sentient creatures are turned into chicken wings, hamburgers and hot dogs.

It is not surprising that the industrial livestock husbandry and slaughter system would like to keep its practices from becoming more visible; whatever else it may do, it causes a large amount of animal suffering, whether from being crowded together, branded, debeaked, or separated from family members (Singer 1990, Pachirat 2011). Economies of scale and negative welfare externalities also make it economical for these larger operations to ignore death rates that would be untenable in smaller systems (Eisnitz 1997). Even when farming operations set out to treat their livestock humanely, there remains the possibility of harm due to accidents, disease, negligence, and poor veterinary care or exposure to the elements.

All else being equal, animals are more likely to experience harm in a system that keeps them invisible. Accountability for the treatment of animals presupposes at least keeping track of how many are killed. Tracking the number of animals killed is thus arguably justified as a means of increasing their visibility and so increasing 
the likelihood of greater responsibility for their treatment overall, as it pertains not only to killing but also suffering.

While the ethical and political dimensions of food are now widely recognized, less attention has been devoted to analyzing the ethical and political role cookbooks play in guiding food choices, particularly as they pertain to animals. In addition, while not all influential cookbooks achieve that status because they are authored by celebrities, the media prominence of television chef makes it more likely that their books will be published, publicized and purchased. The central contribution of this paper is therefore to measure the number of sentient animals required to make all the recipes in a given cookbook. We do not evaluate here how much ethical weight should be given to sentient animal death vis-a-vis environmental or other concerns, nor do we attempt to measure indirect harms or to account for how the distributed nature of the global food system complicates our chosen method. We do, however, supplement our kill index with qualitative data drawn from our texts. We single out individual chefs for discussion and focus on the following: 1) whether their selfpresentation reflects their place on the index; 2) the extent to which their food recommendations are either hedonistic and indulgent or responsible and frugal (either intentionally or not); and 3) the extent to which authors focus on food providence, ecological and welfare concerns, and one's positioning with respect to the existing industrial food system.

\section{Material and Method}

We selected 30 cookbooks by 26 celebrity chefs as the basis from which to construct our animal kill index. Chefs were selected that have had a national television program somewhere in the English-speaking world since 2000. In most cases the chefs' most popular texts were selected, with popularity assessed by 
looking at books' appearance on bestseller lists and their Amazon.com rankings, and then by listing the number of ratings they received on Goodreads.com. We focused on Goodreads reviews because it provides a simple measure (ratings) of book popularity and is the most popular site of this nature. The indexed books were published between 1993 and 2015.

Specific cookbooks were selected to provide a balance between popularity on Goodreads.com, television celebrity status, and the type of books the author has written. In some cases the most popular book was too much of a niche cooking product (all bakery, all desserts, etc.) to provide an accurate representation of a given chef's style so a more general-purpose and everyday-use cookery book by that author was selected instead. If an omnivorous chef had also published a vegetarian cookbook or a cookbook with an ethical rationale (e.g. a cookbook with an environmental motivation), we also included the vegetarian or ethical book. This resulted in four chefs having two index entries. Hugh Fearnley-Whittingstall, Yotam Ottolenghi and Rachael Ray each published a vegetarian cookbook, while Mario Batali's Molto Gusto is co-authored with "flexitarian" (i.e. semi-vegetarian) chef Mark Ladner and has an ethical rationale (which we discuss below) (Food and Wine 2010). ${ }^{4}$

\footnotetext{
${ }^{4}$ For a bit more detail on the Goodreads numbers: Batali's Molto Italiano (2005) topped out our list, with 31,885 Goodreads reviews, as accessed on April 8 2017. Batali (2010), Bayless (2005), and Bourdain (2004) each had around twenty thousand reviews. Colicchio (2003) and Deen (1998) each around ten thousand, Drummond (2009) Fearnley-Whittingstall (2001, 2011) and Fieri (2011) all garnering around five thousand reviews. (Some of the authors of books much further down on the list (Lawson 2007, with 278 reviews, or Ottolenghi 2010, with 171 reviews) also had memoirs or other hybrid books with ratings in the mid-thousands.) Ratings of below one hundred Puck (2004), at 77; Ramsay (2001), at 60, Ray (2001, 2005), at 52 and 24; Romero et al (2015), at 14; Samuellsson (2014), at 2; and Stone (2013), at 1 review. We selected, in other words, both for clearly popular books and for less popular books by authors who: have blockbuster TV shows (Ray, Ramsay) or have won shows such Top Chef Masters (Samuellsson), operate a well-known franchise (Puck), maintain a substantial following in some part of the Englishspeaking world, such as in Australia (Stone), or books that are specifically vegan (Romero et al). While we are agnostic about the specific mechanisms of celebrity influence on consumer behavior and even
} 
To construct the index, we entered pertinent data for each the recipes from each book into a spreadsheet. ${ }^{5}$ For each recipe, we included the recipe type, the number of servings, and two distinct columns for animal ingredients, the first including all carcass parts from sentient animals, which we define as conscious entities capable of experiencing pleasure and pain. For the purposes of our index we took sentience to be a trait primarily of vertebrates. Although we do not rule out the possibility that compelling evidence for sentience in invertebrate animals may someday emerge, we interpret contemporary findings in animal sentience to broadly exclude such invertebrates as sea urchins, jellyfish, molluscs, crustaceans, insects and most cephalopods (Varner 1998: 53; Tye 2017). As a result, although the cookbooks under examination frequently used invertebrates, our index did not record their deaths. For reasons to be discussed shortly below, the one exception to this exclusion rule concerns octopus. Our index thus tracked the use of vertebrates and octopi (or ingredients that include any such parts, such as from the anchovies in Worcestershire sauce). After entering the data, we swapped books and doublechecked each other's work by randomly checking the accuracy of coding for at least 10 recipes in each book. Two coders then independently calculated the overall number of animal deaths required for each book and reconciled any discrepancies.

Parameterizing the kill list inevitably required discretionary choices, which we made on the basis of attempting to be as transparent as possible. Our method of calculation employs the following assumptions:

preferences but point out that some such mechanisms do appear to be operative, and our sampling method was designed to pick up signals coming from places other than the most popular books.

${ }^{5}$ Available at andylamey.com. 
- We limit the kill list to the number of carcasses required to provide the listed ingredients in a recipe; this does include the use of rennet in some cheese products, but does not include more indirect deaths, such as the projected number of productive animal lives required to produce a given amount of milk or eggs. ${ }^{6}$ Of course animals routinely die in large numbers to provide milk and eggs. Our goal, however, was to calculate the absolute minimum number of animal deaths required to make every non-dessert recipe in each book, and in principle a user of any given cookbook could obtain eggs or milk from free-range backyard animals. While this happens rarely in most urban settings, it demarcates animal deaths absolutely required by the recipes themselves, as opposed to deaths that are due to the user's decision to purchase products from the industrial milk and egg industry.

- We include all non-dessert or drink recipes and ignore serving sizes. Serving sizes are ignored both because most recipes averaged out at around 4 servings and because different authors had different measures for what constitutes a serving.

- If a recipe listed options, such as vegetable vs. chicken broth, we included the first such option listed. Sometimes this was a vegetarian option, and sometimes not. Similarly, if a recipe called for leftovers the specified item left over was excluded from the final list to avoid double-counting.

- Other indirect and more broadly ecological or human equity harms—such as bycatch from wild-caught fish, the effects of palm oil on orangutan habitat, or human equity concerns in tropical sugar or cocoa production-were also

\footnotetext{
${ }^{6}$ We tabulated a total of 2138.5 eggs used (with a high of 296 in Paula Deen's book and an average close to 75). This would still only amount to the productive lives of around nine chickens. We thank Natalie Terenzi for assistance calculating these figures.
} 
excluded for present purposes. Our study strictly limits itself to constructing a clear measure for the number of sentient animals required to be killed by the recipes called for in a given celebrity chef's cookbook.

We then constructed a series of measures for putting animal carcasses together. For commonly used larger terrestrial animals this entailed calculating dressing percentage and carcass-cutting yields, and then finding reliable sources for the weight of different cuts and types of meat. ${ }^{7}$ The first choices here were publications either from the USDA or an agricultural university program, the second online butcher shops. ${ }^{8}$ For cows and pigs we primarily used cowweight and hogweight for the amount of different cuts that come from different regions.

Because our measure is constructed to indicate the minimum total number of animals required, in the case of chickens the most important thing was whether the chef called for a disproportionately large amount of one animal part relative to others. As a result chicken kill numbers were determined not the by average broiler chicken weight and dressing ratios, but simply by the comparative number of wings, legs, breasts, and other parts a cookbook used. The largest such number dictates the number of animals required. For an example: a collection of recipes that calls for 46 wings, 16 full breasts, 20 drumsticks, and 12 full legs would require 23 chickens because of the wings; with fewer wings it would only have required 16, because both the drumsticks and the full legs require the same body parts.

\footnotetext{
${ }^{7}$ The dressing percentage is the percentage of the live animal that remains as carcass after skinning and evisceration, a process that normally removes the hide, head feet and entrails. Raines (1999) provides the following Approximate dressing ratios: pork (70\%), cattle (60\%), sheep (50\%); from carcass to cuts, with pork $65-70 \%$ boneless and $75-80 \%$ bone-in, beef $55-60 \%$ boneless and $65-70 \%$ bone-in, lamb $70-$ $75 \%$.

${ }^{8}$ Such as at http://www.clovegarden.com/ingred/ap_pigc.html.
} 
Measuring direct fish kills required is more complicated and less precise. The wide variety in sizes of a number of larger fish required some approximation but involved finding an average pre-dressing weight for each species and then estimating that a fish can yield $65 \%$ of that estimate in fillets. In most cases small fish had a much bigger impact on the kill index than large ones.

In the case of commonly used terrestrial animals we assumed a live weight of 544.3 kilos (1,200 lbs) for cattle, 113.4 kilos (250 lbs) for pigs and 2.7 kilos (six lbs.) for chicken. From this live weight animals and then dressed and their carcasses cut, and some weight is lost at each stage. ${ }^{9}$ To determine how much meat each individual animal provides we employed industry carcass-cutting yields of $43 \%$ for cattle, 58\% for pigs and 75\% for chicken (ODAFF 2017a; ODAFF 2017b). We similarly employed widely used industry assumptions to calculated carcass sizes and yields for other food animals such as lambs and turkeys (Raines 1999; National Turkey Federation 2017).

In the cases of the larger and more common terrestrial animals-cows, pigs, sheep, turkeys, ducks, and chickens-we constructed a grid of animal parts and their average weights with respect to the total animal, and then filled in that grid. A chicken, for instance, has two breasts, two legs, two wings, and two thighs, as well as its various organs and appendages and the stock or broth that can be made from its bones and remaining parts. And so on, in a similar manner, for pigs, cows, lamb, ducks, and other less commonly used terrestrial animals. A cookbook that calls for 4.5 kilos (10 lbs.) of flank steak will thus require at minimum three cows, while a book calling for 22.5 kilos (50 lbs.) of chuck steak would require only one. This is

\footnotetext{
${ }^{9}$ See the first page of the data sheet for sources on approximate weights for the around 25 larger fish species that our chefs called for.
} 
because our average cow has only 1.75 kilos ( $3.9 \mathrm{lbs}$ ) of flank steak on its body, but over 70 kilos (163.8 lbs) of chuck steak and related cuts (Holland et at. 2014).

Because our project involved counting the death of sentient animals, it required us to draw a boundary between sentient and non-sentient organisms. We consider it uncontroversial to ascribe sentience to mammals. That we additionally ascribed sentience to chicken and fish was no accident. While it was once widely accepted that neither category of animal possessed cognitive capabilities comparable to mammals, and so warranted a lower degree of moral standing, this view is not supported by contemporary research on animal cognition in the fields of comparative psychology and cognitive science.

In the case of chickens, for example, recent findings have led to a revision of our understanding of their cognitive capabilities, as evident in the decision of the Avian Brain Nomenclature Consortium to adopt a new terminology to describe avian brain regions and functions (Jarvis et al 2005). Where chickens and other birds were traditionally thought to be incapable of non-instinctive behaviour because they lacked a neocortex, it is now recognized that functions mammals perform in their neocortex, such as recognizing patterns, understanding the mental states of others and engaging in forms of communication that are deliberate rather than merely instinctive, are performed by birds in other parts of their brain (Kaplan and Rogers 2005). Similarly, the traditional view of chickens as having no sense of the past or future has been undone by studies involving food-control trials. In such studies chickens consistently prefer waiting longer for a larger food jackpot, an outcome which requires them to be able to discriminate between shorter and longer waiting times (Abeyesinghe et al. 2005; Taylor et at. 2002). These and other findings 
disputing the limited view of chicken cognition are now well documented in avian cognition research (Rogers and Kaplan 2004: vii; Regolin et al 2005). ${ }^{10}$

Recent research on the cognitive capabilities of fish has been equally revisionary, and supports the view that there is no reason based on their cognitive capabilities to deny that fish are sentient. ${ }^{11}$ As one overview of research on fish cognition puts it, "gone (or at least obsolete) is the image of fish as drudging and dim-witted pea brains, driven largely by 'instinct,; with what little behavioral flexibility they possess being severely hampered by an infamous 'three-second memory'" (Laland et al. 2003: 199-200). Recent findings regarding fish sentience include the fact that fish have nociceptors that transmit pain signals to the brain in a manner similar to that found in other vertebrates; the behaviour of fish is thus negatively effected by painful stimuli (Sneddon et al. 2003). The researchers who documented these findings subsequently injected the lips of rainbow trout with chemical stimuli (vinegar, bee venom) to which fish responded with increased breathing and reduced appetite, reactions similar to those of other vertebrates in pain. Additional research has revealed that administering morphine to trout that had been injected with noxious chemicals significantly diminished the fishes' pain-related reactions (Sneddon 2003; Sneddon and Leach 2016). In addition to pain, Chandaro et al (2004) argue that fear and stress are evident as well. Such findings have been subsequently confirmed in follow-up studies and meta-analyses (Chandroo et al. 2004; Sneddon 2007; Braithwaite and Boulcott 2008; Nordgreen et al. 2009; Brown et al. 2011). Findings of this kind have co-incided with increased concern for the welfare of fish

\footnotetext{
${ }^{10}$ For discussion of the ethical significance of recent findings in avian cognition see Lamey 2012.

${ }^{11}$ This is again not to deny that they may have differential moral status based on cognitive, behavioral and social-structural differences, but that we are concerned here with measuring and making these questions of basic standing in the context of celebrity influence and the ethics of individual food choices.
} 
in the aquaculture industry (which produces the majority of the world's fish supply) as well as the suffering of wild-caught fish. ${ }^{12}$ Given the state of research regarding chicken and fish sentience and the emphasis for our purposes on the killing of at least minimally sentient creatures, our index makes no distinction between mammals, birds and fish, or between fish of different sizes.

The only non-vertebrate species we counted was octopus. The case of the octopus illustrates a difficulty with benchmarking cognition only to vertebrates, as cephalopods evolved complex cognition in a separate evolutionary pathway from mammals (Godfrey-Smith 2013; 2016). There is, however, evidence of a number of behaviors and faculties present in octopi that suggest that they are conscious. They depend on learning visual clues to forage in their environments, developing memory and possibly primary consciousness (Mather 2008). They also show evidence of play behavior (Kuba et al 2006), the ability to recognize individual humans (Anderson et al 2010), and the ability to learn conditionally (Hvorecny et al 2007). We include octopus but parsimoniously, for the present, and from the perspective of minimal sentience, exclude other cephalopods—such as cuttlefish, which Hvorecny et al also show can learn conditionally- because the evidence to date is more convincing for octopi.

\section{Results}

The books we examined exhibited a wide range in the average number of animals killed per recipe, from zero to 5.25 (Figure One). We divided the books into four levels, according to how many animal lives they required per recipe. Books at

\footnotetext{
${ }^{12}$ The National Oceanic and Atmospheric Administration (2012) notes that more than fifty percent of fish produced for human consumption now comes from aquaculture. For discussion of the welfare issues of farmed and wild-caught fish seen respectively the Humane Society of the United States (2010) and Mood (2010). For a discussion of the latter see Singer (2010).
} 
level one required zero while those at level two required up to 0.5 . Level three books required up to one animal per recipe while those at level four required over one animal per recipe.

Figure One: Average Number of Sentient Animal Deaths Per Recipe

\begin{tabular}{|c|c|c|c|c|c|}
\hline $\begin{array}{l}\text { Average } \\
\text { Deaths/ } \\
\text { Recipe }\end{array}$ & Chef & $\begin{array}{l}\text { Network } \\
\text { Affiliation(s) }\end{array}$ & Book & $\begin{array}{l}\text { Total } \\
\text { Deaths }\end{array}$ & $\begin{array}{l}\text { Leading } \\
\text { Species }\end{array}$ \\
\hline 5.25 & Mario Batali & $\begin{array}{l}\text { ABC (US) } \\
\text { Food (US) }\end{array}$ & $\begin{array}{l}\text { Molto Gusto: Easy } \\
\text { Italian Cooking (2010) }\end{array}$ & 620 & $\begin{array}{l}567 \text { glass } \\
\text { eels }\end{array}$ \\
\hline 2.85 & Susur Lee & $\begin{array}{l}\text { Food (CAN) } \\
\text { HGTV (CAN) }\end{array}$ & $\begin{array}{l}\text { Susur: A Culinary Life } \\
\text { (2005) }\end{array}$ & 268 & 188 squab \\
\hline 1.32 & Mario Batali & $\begin{array}{l}\text { ABC (US) } \\
\text { Food (US) }\end{array}$ & $\begin{array}{l}\text { Molto Italiano: } 327 \\
\text { Simple Italian Recipes to } \\
\text { Cook at Home (2005) }\end{array}$ & 384 & $\begin{array}{l}185 \\
\text { Anchovies }\end{array}$ \\
\hline 1.23 & $\begin{array}{l}\text { Gordon } \\
\text { Ramsey }\end{array}$ & $\begin{array}{l}\text { FOX (US) } \\
\text { Channel } 4 \\
\text { (UK) }\end{array}$ & $\begin{array}{l}\text { Gordon Ramsey's Fast } \\
\text { Food: Recipes from the } \\
\text { F Word (2009) }\end{array}$ & 127 & $\begin{array}{l}71 \\
\text { anchovies }\end{array}$ \\
\hline $\begin{array}{l}\text { Average } \\
\text { Deaths/ } \\
\text { Recipe }\end{array}$ & Chef & $\begin{array}{l}\text { Network } \\
\text { Affiliation(s) }\end{array}$ & Book & $\begin{array}{l}\text { Total } \\
\text { Deaths }\end{array}$ & $\begin{array}{l}\text { Leading } \\
\text { Species }\end{array}$ \\
\hline 0.69 & $\begin{array}{l}\text { Nigella } \\
\text { Lawson }\end{array}$ & $\begin{array}{l}\mathrm{ABC} \text { (US) } \\
\mathrm{BBC} \text { (UK) }\end{array}$ & $\begin{array}{l}\text { Nigella Express: } 130 \\
\text { Recipes for Good Food, } \\
\text { Fast (2007) }\end{array}$ & 84 & 25 chicken \\
\hline 0.64 & Tom Colicchio & Bravo (US) & Craft of Cooking (2003) & 62 & 13 chicken \\
\hline 0.63 & Mark McEwan & $\begin{array}{l}\text { Food } \\
\text { (Canada) }\end{array}$ & $\begin{array}{l}\text { Great Food At Home: } \\
\text { Family-style Recipes For } \\
\text { Everyday (2010) }\end{array}$ & 60 & 21 chicken \\
\hline 0.63 & $\begin{array}{l}\text { Anthony } \\
\text { Bourdain }\end{array}$ & $\begin{array}{l}\text { Food (US) } \\
\text { Travel (US) } \\
\text { CNN (US) }\end{array}$ & $\begin{array}{l}\text { Anthony Bourdain's Les } \\
\text { Halles Cookbook }\end{array}$ & 65 & 10 whitebait \\
\hline 0.62 & $\begin{array}{l}\text { Hugh } \\
\text { Fearnley- } \\
\text { Whittingstall }\end{array}$ & $\begin{array}{l}\text { Channel } 4 \\
\text { (UK) }\end{array}$ & $\begin{array}{l}\text { The River Cottage } \\
\text { Cookbook (2001) }\end{array}$ & 66 & 12 chicken \\
\hline
\end{tabular}




\begin{tabular}{|c|c|c|c|c|c|}
\hline 0.6 & $\begin{array}{l}\text { Jeff } \\
\text { Henderson }\end{array}$ & Food (US) & $\begin{array}{l}\text { Chef Jeff Cooks: } \\
\text { In the Kitchen with } \\
\text { America's Inspirational } \\
\text { New Culinary Star (2008) }\end{array}$ & 61 & 48 chicken \\
\hline 0.59 & $\begin{array}{l}\text { Padma } \\
\text { Lakshmi }\end{array}$ & Bravo (US) & $\begin{array}{l}\text { Tangy, Tart, } \\
\text { Hot and Sweet (2007) }\end{array}$ & 57 & $\begin{array}{l}24 \\
\text { anchovies }\end{array}$ \\
\hline 0.55 & Guy Fieri & Food (US) & $\begin{array}{l}\text { Guy Fieri Food: Cookin' } \\
\text { It, Livin' It, Lovin' It (2011) }\end{array}$ & 71 & 37 chicken \\
\hline 0.52 & $\begin{array}{l}\text { Yotam } \\
\text { Ottolenghi }\end{array}$ & $\begin{array}{l}\text { Channel } 4 \\
\text { (UK) }\end{array}$ & $\begin{array}{l}\text { Ottolenghi: The Cookbook } \\
\text { The Cookbook (2008) }\end{array}$ & 46 & 9 chicken \\
\hline $\begin{array}{l}\text { Average } \\
\text { Deaths/ } \\
\text { Recipe }\end{array}$ & Chef & $\begin{array}{l}\text { Network } \\
\text { Affiliation(s) }\end{array}$ & Book & $\begin{array}{l}\text { Total } \\
\text { Deaths }\end{array}$ & $\begin{array}{l}\text { Leading } \\
\text { Species }\end{array}$ \\
\hline 0.5 & Ina Garten & Food (US) & $\begin{array}{l}\text { The Barefoot Contessa } \\
\text { Cookbook (1999) }\end{array}$ & 34 & 21 chicken \\
\hline 0.45 & Rachael Ray & Food (US) & $\begin{array}{l}\text { Rachael Ray } 365 \text { No: } \\
\text { Repeats A Year of } \\
\text { Deliciously Different } \\
\text { Dinners (2005) }\end{array}$ & 165 & 75 chicken \\
\hline 0.39 & Curtis Stone & $\begin{array}{l}\text { ABC (AUS) } \\
\text { Bravo (US) } \\
\text { Fox (US) }\end{array}$ & $\begin{array}{l}\text { What's for Dinner? } \\
\text { Delicious Recipes for } \\
\text { a Busy Life (2013) }\end{array}$ & 38 & 21 chicken \\
\hline 0.39 & Rick Bayless & PBS (US) & Mexican Everyday (2005) & 32 & 17 chicken \\
\hline 0.37 & Emeril Lagasse & $\begin{array}{l}\text { Food (US) } \\
\text { Planet } \\
\text { Green (US) }\end{array}$ & $\begin{array}{l}\text { Emeril's New New } \\
\text { Orleans Cooking (1993) }\end{array}$ & 71 & 43 chicken \\
\hline 0.33 & $\begin{array}{l}\text { Ree } \\
\text { Drummond }\end{array}$ & Food (US) & $\begin{array}{l}\text { The Pioneer Woman } \\
\text { Cooks: Recipes From } \\
\text { an Accidental } \\
\text { Country Girl (2009) }\end{array}$ & 41 & 32 chicken \\
\hline 0.33 & Marcus & Food (US) & Marcus off Duty: The & 37 & 14 chicken \\
\hline
\end{tabular}




\begin{tabular}{|c|c|c|c|c|c|}
\hline & Samuelsson & ABC (US) & $\begin{array}{l}\text { Recipes I Cook at Home } \\
\text { (2014) }\end{array}$ & & \\
\hline 0.32 & $\begin{array}{l}\text { Wolfgang } \\
\text { Puck }\end{array}$ & Food (US) & $\begin{array}{l}\text { Wolfgang Puck Makes } \\
\text { It Easy: Delicious } \\
\text { Recipes For Your } \\
\text { Home Kitchen (2004) }\end{array}$ & 38 & 15 chicken \\
\hline 0.31 & Paula Deen & Food (US) & $\begin{array}{l}\text { The Lady \& Sons } \\
\text { Savannah Country } \\
\text { Cookbook (1998) }\end{array}$ & 61 & 20 chicken \\
\hline 0.3 & Jamie Oliver & $\begin{array}{l}\text { BBC (UK) } \\
\text { ABC (US) } \\
\text { Ten (AUS) }\end{array}$ & $\begin{array}{l}\text { Jamie's 30-Minute } \\
\text { Meals (2010) }\end{array}$ & 49 & $\begin{array}{l}27 \\
\text { Anchovies }\end{array}$ \\
\hline 0.19 & $\begin{array}{l}\text { Giada } \\
\text { de Laurentiis }\end{array}$ & Food (US) & $\begin{array}{l}\text { Everyday Italian: } \\
125 \text { Simple And } \\
\text { Delicious Recipes (2005) }\end{array}$ & 20 & 10 chicken \\
\hline 0.09 & Rachael Ray & Food (US) & $\begin{array}{l}\text { Veggie Meals: Rachael } \\
\text { Ray's 30-Minute Meals } \\
\text { (2001) }\end{array}$ & 9 & 6 anchovies \\
\hline $\begin{array}{l}\text { Average } \\
\text { Deaths/ } \\
\text { Recipe }\end{array}$ & Chef & $\begin{array}{l}\text { Network } \\
\text { Affiliation(s) }\end{array}$ & Book & $\begin{array}{l}\text { Total } \\
\text { Deaths }\end{array}$ & $\begin{array}{l}\text { Leading } \\
\text { Species }\end{array}$ \\
\hline 0.01 & Toni Fiori & PBS (US) & $\begin{array}{l}\text { Totally Vegetarian: Easy, } \\
\text { Fast, Comforting } \\
\text { Cooking for Every Kind } \\
\text { of Vegetarian (2008) }\end{array}$ & 1 & 1 cow \\
\hline 0 & $\begin{array}{l}\text { Hugh - } \\
\text { Fearnley } \\
\text { Whittingstall }\end{array}$ & $\begin{array}{l}\text { Channel } 4 \\
\text { UK) }\end{array}$ & $\begin{array}{l}\text { River Cottage Veg: } \\
200 \text { Inspired Vegetable } \\
\text { Recipes (2011) }\end{array}$ & 0 & N/A \\
\hline 0 & $\begin{array}{l}\text { Yotam } \\
\text { Ottolenghi }\end{array}$ & $\begin{array}{l}\text { Channel } 4 \\
\text { (UK) }\end{array}$ & $\begin{array}{l}\text { Plenty: Vibrant Vegetable } \\
\text { Recipes from London's } \\
\text { Ottolenghi (2010) }\end{array}$ & 0 & N/A \\
\hline 0 & $\begin{array}{l}\text { Terry Romero } \\
\text { Et al. }\end{array}$ & $\begin{array}{l}\text { Create (US) } \\
\text { Mashup } \\
\text { Season Two }\end{array}$ & Delicious TV's Vegan & 0 & N/A \\
\hline
\end{tabular}


Ecookbook (2015)

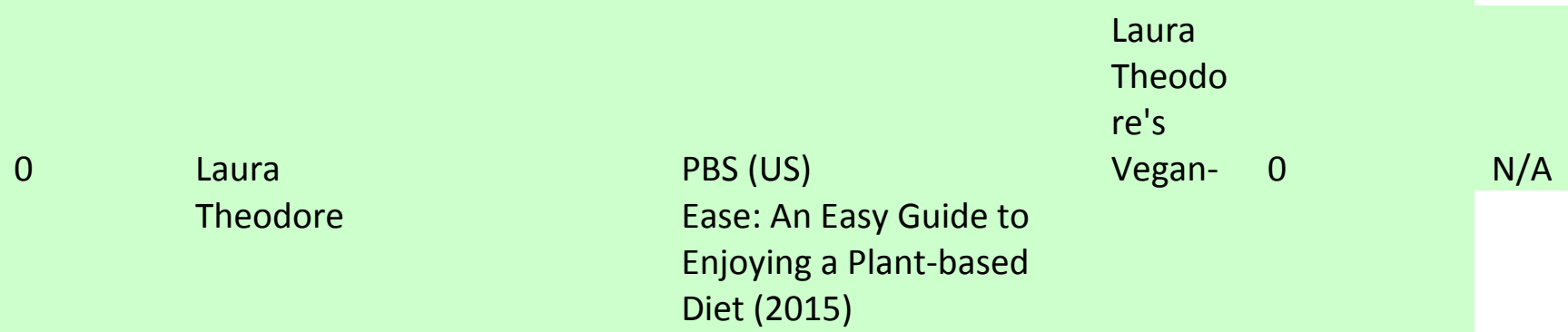

Average deaths $/$ recipe $=$ average number of animal deaths per non-dessert recipe.

Total Deaths = minimum number of animal deaths required to make all nondessert recipes.

Leading species $=$ species with highest number of deaths.

Red $=$ Level Four. Orange $=$ Level Three. Yellow $=$ Level Two. Green $=$ Level One.

Average score $=0.67$ Median $=0.42$ Standard deviation $=1$

Network abbreviations:

ABC (AUS) = Australian Broadcasting Corporation

$\mathrm{ABC}(\mathrm{US})=$ American Broadcasting Company

BBC $(\mathrm{UK})=$ British Broadcasting Corporation

PBS (US) = Public Broadcasting Service

At the lower end, four books had an average animal footprint of zero. Two of these (Theodore and Romano et al.) were vegan works by chefs with shows on the U.S. Public Broadcasting Station (PBS). Two more prominent chefs, Hugh FearnleyWhittingstall and Yotam Ottolenghi, also had books with average rankings of zero, although in their cases the books in question were vegetarian rather than vegan.

Two vegetarian cookbooks, by Toni Fiori (0.009) and Rachael Ray (0.09), had a score higher than zero, albeit marginally so in Fiori's case. Fiori and Ray's recipes occasionally called for particular cheeses that contain rennet, such as gorgonzola 
dolce and fresh mozzarella. Although Fearnley-Whittingstall and Ottolenghi also use cheeses, they do not instruct the reader to use types that contain rennet. Their lower rankings are reflected in their recipes always leaving open the option of using vegetarian cheeses, which Fiori's and Ray's did not (Ray also called for anchovies and Worcestershire sauce in some of her recipes).

Giada de Laurentiis (0.19) had the lowest score among omnivorous chefs (0.19). It is noteworthy that her book Everyday Italian and the book with the very highest score, Mario Batali's Multo Gusto (5.25) both specialize in Italian cuisine. Nothing in the presentation or marketing of either book would lead one to suspect that they have such different animal footprints. Indeed, de Laurentiis's book includes a foreword by Batali, emphasizing their shared culinary approach, one of dedication to "simple Italian food." (2005: 7). For her part, De Laurentiis presents her recipes as simple, fun and fast. She expresses no interest in vegetable-forward dishes and mentions no concerns related to food ethics. Conversely, nothing in the presentation of de Laurentiis's book would lead one to think that it had an especially small footprint for an omnivorous work. In neither case is there a visible connection between the book's self-presentation and its harm footprint.

In addition to Molto Gusto, three other books also appeared in level four. They were by Susur Lee, Gordon Ramsey and an additional book by Batali, Molto Italiano. Molto Italiano was the original book selected to represent Batali's approach to cooking. It is somewhat ironic that it received a lower score than Molto Gusto, Batali's ethically informed work. That Batali's more conscientious mode of cooking resulted in a higher animal harm footprint illustrates the potential for an otherwise conscientious food ethic to overlook moral considerations regarding animals. That 
Batali had two works with high animal death counts marks him as the chef with the largest animal harm-footprint in our index.

In the cases of Molto Italiano and the level-four books by Lee and Ramsey, the high count in each case was due to a consideration that is frequently overlooked in discussions of dietary ethics: the physical size of food animals. Ramsey, for example, required only one each of cows and pigs, but 71 anchovies. (Liberal use of small fish such as sardines, anchovies and sprats elevated Ramsey's kill ratio substantially, and this was also the case for chefs who often use Worcestershire sauce or anchovy paste.) Like Ramsey's count, Lee's was disproportionately due to one small species, in his case, 188 squab. As for Mondo Italiano, while only one pig and three cows were required to make its pork and beef dishes, other dishes in Batali's book required 46 sardines, 37 chicken, 25 octopi and 16 quail. Books by Jamie Oliver and Paula Deen with far lower counts are mostly accounted for by their more frugal use of small animals. Oliver, for example, was sparing with anchovies (27) and chicken (7), while Deen—favoring meat from large animals— used only 20 chickens and no anchovies. The final column in Figure One identifies the individual species of food animal with the highest death count for each book. In the case of every omnivorous book this was either chicken or some type of seafood.

\section{Discussion}

Several aspects of our index warrant comment. Here we focus on three: the varying harm footprints of different forms of omnivorism; cases in which chefs' placement on the index do and do not match the approach to cooking represented in their public image; and the culinary philosophies of the two most well-known chefs who authored books with harm footprints of zero, Hugh FearnleyWhittingstall and Yotam Ottolenghi. 


\section{Omnivorism's Varying Harm Footprint}

It is now common to distinguish between veganism or vegetarianism on the one hand and omnivorism on the other. That some omnivorous chefs had dramatically higher animal harm footprints however suggests a need to distinguish between different forms of omnivorism. The high kill rates of Batali, Lee and Ramsey illustrates an especially deadly approach to cooking with meat, one that, were it widely adopted, would significantly increase the number of sentient animal deaths compared to conventional omnivorism. Conversely, Oliver and Deen, and especially de Laurentiis, represent forms of omnivorism with significantly smaller animal harm footprints. In the case of Oliver this may partly be due to his widely publicized interest in meat-reduced cooking (Telegraph Food 2015). Deen however is similar to de Laurentiis in that her book is associated with a regional cuisine-in her case that of the Southern United States-rather than any conscious dedication to eating less meat. Thus her low score, alongside de Laurentiis', appears to be a byproduct (either intended or not, but at least not stated) of her cooking style. In its focus on generous portions of large-animal meat and dairy, however, Deen's food, like Fieri's, is most likely unhealthy, and could result in self-harm that itself fails to balance between hedonism and responsibility. Nevertheless, with these caveatsand from the perspective of sentient death -the approaches of de Laurentiis, Oliver and Deen's books may represent a worthwhile first step for someone seeking to transition slowly from conventional to plant-based eating, or anyone seeking a form of "reducetarianism" that is based in part on an ethical concern for animals.

Of the authors surveyed, 14 make no mention of ethical issues such as animal treatment or environmental concerns, although some of these (Ray, Bayless) do mention the health benefits of eating a plant-based diet. Others mostly discuss their 
families and life stories (which in Henderson's case includes mention of his family members who follow vegetarian or vegan diets). Some do mention free-range meats (Puck) or specify vegetarian options in their books (Fieri, Ramsay), but nothing more.

Index ranking vs. Self-presentation

Many of the selected TV chef personalities are also known for caring about a particular issue, or for having particular temperament. On television, Guy Fieri is known for travelling around the country going to diners and dive bars, dishing up enthusiasm and eating large portions of meat-centric foods; indeed, in his cookbook he refers to his "honor" working with the National Pork Board ((Hsu 2016, Fieri 2011: 210). Anthony Bourdain is famous both for his adventurous eating and travel and for his scorn of animal rights activists and vegetarians (discussed in more detail below). Jamie Oliver campaigns for a "food revolution" in healthy school lunches and against obesity, both in the UK and the USA, and has a reputation for trying to get people to eat healthy foods and be mindful of environmental as well as animal issues (Spence 2005). ${ }^{13}$ Gordon Ramsay is known for his demanding culinary standards and the fiery temper that erupts when they are not met (Buford 2007). Paula Deen is known for cooking rich and indulgent foods such as donut hamburgers, and, more recently, for concealing her own diabetes diagnosis while continuing to cook this and other such food on television (Italie 2012).

In this light, it is interesting to compare chefs' reputations and their selfpresentation in the cookbooks to their place in the animal kill index. While Oliver has gained publicity for his interest in a variety of ethical issues related to food,

${ }^{13}$ Oliver's public persona has frequently been subject to critical commentary. For examples see Andreou (2013), Self (2013) and Bowater and Foster (2016). 
Ramsey and Lee make no pretense of concern for animal welfare and instead approach food as something that brings pleasure above all. The place of all three of these chefs in the index is consistent with their public image.

In other cases, however, this is less straightforwardly true. Consider Batali's Molto Gusto, which is presented as an ethically conscious work. "In the last few years, the idea that there are social costs associated with the decisions we make at the grocery store and at the table have become quite compelling," author Mario Batali writes. He notes that his restaurants no longer serve imported bottled water and have become "green-certified" at most locations through a combination of efficient lighting, composting and recycling. The meat sold in his restaurants is hormone free, and his menus increasingly have "less and less protein as the main event ... [because] our protein-heavy diet has far-reaching implications, including energy and resource management as well as global warming" (2010: 12). Batali here associates protein with meat-based dishes. In eschewing a protein-heavy approach Batali thus suggests his focus is on vegetables, a suggestion that was reiterated in coverage of his book in the culinary media (Food and Wine 2010).

Based on the presentation of De Laurentiis and Batali's books, a reader interested in reducing his or her animal footprint could be forgiven for thinking that Molto Gusto, with its spirit of ethical consciousness and avowed openness to vegetableforward dishes, would result in a fewer animal deaths. In reality the book had an extremely large animal footprint, primarily due to one recipe calling for 0.9 kilos of glass eels..$^{14}$

\footnotetext{
${ }^{14}$ We initially wondered whether to include glass eels, which are eels in an early developmental state, between the larval and juvenile stages. Might it be the case that glass eels do not feel pain? Adult eels are in fact known to respond to pain stimuli, and we are unaware of any vertebrate species that feels pain as an adult but not a juvenile. Indeed, from an evolutionary point of view it is not clear how an
} 
If Batali and De Laurentiis's are noteworthy for having harm footprints far larger than their presentation would suggest, other chefs are noteworthy for having harm footprints far more similar than one might expect. Consider the contrasting selfpresentations of Padma Lakshmi and Guy Fieri. Lakshmi is the host of Top Chef, a reality competition show that frequently features gourmet chefs as competitors or judges. Fieri, by contrast, cultivates an image as a populist anti-gourmet. His television show Diners, Drive-ins and Dives celebrates unpretentious comfort food. Lakshmi has described her own diet as being mostly vegetarian outside of Top Chef, while Fieri's work is informed by an outspoken love of meat. Yet the two food personalities resulted with very similar scores, 0.59 and 0.55 respectively, with Fieri's coming in beneath Lakshmi's. Fieri's recipes do not include glass eels, octopus and other exotic meats, but focus instead on the familiar trilogy of beef, pork and chicken. One whole section of his book is devoted to pork recipes, while another focuses on Beef \& Lamb. He discusses his collaboration with the National Pork Board with pride. Fieri's emphasis on Beef and Pork is in keeping with his image as a chef who specializes in masculine food: his television persona has been well characterized as one that combines a love of American comfort food with a commitment to old-fashioned values such as "work ethic, devotion to family [and] gender traditionalism" (Johnston et al 2014: 17). Fieri's working-class populist approach to food has been subject to extensive criticism and even ridicule, and certainly it is noteworthy how unhealthy his recipes often are (Salkin 2013; Wells 2012). Fieri's place in our index was respectable, however, scoring better than

animal could develop the capacity to feel pain only after the juvenile stage of its life-cycle. For responses to pain-stimuli in adult European eels see Lambooij et al. $2002 a$ and $2002 b$. For welfare aspects of killing European eels see Salman et al. (2009). For a discussion of handling stress in glass eels see Wilson (2013) 334-8. 
Lakshi, a self-identified vegetarian and only slightly behind Ottolenghi's omnivorous book.

Another odd pairing on the index were the omnivorous books by Anthony Bourdain and Hugh Fearnley Whittingstall. Bourdain has long cultivated an image as a hedonistic chef who ridicules an ethical concern with animals. "Vegetarians, and their Hezbollah-like splinter-faction, the vegans, are a persistent irritant to any chef worth a damn," Bourdain wrote in his bestselling memoir, Kitchen Confidential. "Vegetarians are the enemy of everything good and decent in the human spirit, an affront to all I stand for, the pure enjoyment of food" (2000: 78). Bourdain includes similar passages in his Les Halles Cookbook, named after the French brasserie where he served as executive chef. "Anyone not in PETA [People for the Ethical Treatment of Animals], with a profound love of the pleasures of the flesh, should be bowled over," he writes of a foie gras recipe (2004: 88). Similarly, in his introduction to a selection of veal recipes, Bourdain makes light of the suffering of veal calves. "It's not nice what they do to calves to make that pale, tender, and attractive meat we so love. But if I tasted that good after being locked up and immobilized in a dark shed, I wouldn't blame anyone for trying" (2004: 140). ${ }^{15}$ This kind of hedonist cooking and eating is unethical from any perspective that grants weight to reducing unnecessary harm to sentient creatures. Fearnley-Whittingstall's River Cottage Cookbook, by contrast, is presented as a manifesto that, as the front flap of the U.S. edition puts it, will help readers live close to the land "while supporting vibrant local economies, the environment and resourceful use of plants and animals,"

\footnotetext{
${ }^{15}$ Bourdain's approach is shared by Mark McEwan, host of the Canadian edition of Top Chef. McEwan characterized fois gras as "one of the great Canadian food products and a source of considerable culinary prestige abroad (except maybe for in Chicago)," (2010: 54). McEwan is here referencing a 2006 decision by Chicago's City Council to ban foil gras, a decision that was overturned in 2008 (Chicago Tribune 2016).
} 
(Fearnley-Whittingstall 2008). He is highly critical of the modern industrial food system and conscious of considerations of animal welfare, and readers are encouraged to personally catch or raise their own food animals and to use each part of every animal nose to tail. Based on their different self-presentations, one could be forgiven for expecting Bourdain to have an especially high animal count and Fearnley-Whittingstall's non-vegetarian book to have a lower one. In reality, both scored above average in terms of overall animals killed, with results practically indistinguishable from one another.

\section{Critical Approaches to Cooking: Fearnley-Whittingstall and Ottolenghi}

Yet if Fearnley-Whittingstall in his omnivorous mode is distinctive for ranking alongside Bourdain, this by itself does not fully reflect his multifaceted approach to cooking. Fearnley-Whittingstall's second book was distinctive for its index score of zero. In this way it is similar to Ottolenghi's Plenty, also a vegetarian book by an omnivorous chef, and the two works by vegan chefs affiliated with PBS: Laura Theodore's Jazzy Vegetarian and an ecookbook authored by the hosts of Vegan Mashup. It is noteworthy that unlike Fearnley-Whittingstall and Ottolenghi, both PBS cookbooks avoided animal products of any kind. To our knowledge PBS is unique among sampled networks in hosting more than one animal-free cooking program. Yet as precedent setting as PBS's vegan chefs may be, none currently enjoy a media profile or audience akin to the more well-known names on our index. We thus conclude our discussion with an analysis of Fearnley-Whittingstall and Ottolenghi, the two popular authors who come closest to balancing culinary pleasures with ethical considerations. Fearnley-Whittingstall's offers the most sustained and in-depth critique of the industrial food system. His books are distinctive among those in our set for being as much pieces of argumentation, 
persuasion, and a kind of ecological home economics as they are cookbooks. Ottolenghi is instead known mostly for his multicultural Mediterranean cooking, the popularity of his vegetarian recipes in particular, and the fact that he is an Israeli who runs a restaurant with a Palestinian cook, Samir Tamimi. FearnleyWhittingstall in particular, but also Ottolenghi to a lesser degree, are the only chefs surveyed who discuss animal ethics in any level of detail. ${ }^{16}$

Ottolenghi's approach to diet is attentive to ethical concerns, such as concern for animal treatment or ecological issues, while also recognizing the aesthetic and communal values of eating for pleasure. In the introduction to Ottolenghi the author laments how Europeans have been "made to feel guilty about having fun. All of a sudden it is about diets, health, provenance, morals, and food miles. Forget the food itself ... what a mistake!" (Ottolenghi 2008: iii) In Plenty, his vegetarian book, Ottolenghi discusses how some people are principled and others pragmatic vegetarians, and how his book is geared to the latter. His vegetarian book seeks to make a joy of plant-based cooking (Plenty is vegetarian rather than vegan, but Ottolenghi points out that vegans can and should be creative about modifying any of his recipes). In general Ottolenghi's book seeks to make ethical vegetarianism pleasurable. In this way his approach contrasts sharply with that of level-four chefs, whose commitment to gustatory pleasure is unmatched by any corresponding commitment animal ethics. While Ottolenghi acknowledges that the hedonic pleasure we get from food is important, he seeks to balance it against the ethical responsibilities inherent in our food choices.

\footnotetext{
${ }^{16}$ This is true even in regard to the two vegan cookbooks. The Vegan Mashup book contains only recipes and does not discuss food ethics at all, while The Jazzy Vegetarian briefly mentions animal welfare as one of several justifications for veganism (Theodore 2015: 4).
} 
Fearnley-Whittingstall's two books document his family's time working the land and raising and hunting animals at this cottage. His commentary and critique in these books is vocal and sustained. He condemns intensive animal agriculture more bluntly than anyone else: he writes that "most of the meat we eat comes from industrially farmed animals who lead miserable lives and are fed on inappropriate diets," (2001: 10) and that "cheap meat from animals who lived painful and stressful lives, fed on a diet scandalously inappropriate for their species - indeed often it was their own species." (2001: 121).

Because Fearnley-Whittingstall views this as just a part of a deeply problematic global food system, he attempts in these two books to persuade the reader to make themselves a little more self-sufficient and a little less dependent on the power of large retailers. In his case this entails raising and killing one cow, some pigs, and assorted other domestic and wild animals in and near his home. The cover of River Cottage Veg shows Fearnley-Whittingstall carrying a piglet under each arm, and many of the pictures in the book outline how to raise and process (no slaughtering was pictured) the carcasses of these animals. He doesn't expect that most of his readers will undertake all of this right away, but that it may spark an interest in growing one's own vegetables or making some other effort to be more self-reliant and less dependent on, as he views it, a ruthless and predatory food system. Without romanticizing his story too much, it's fair to say that the animals he raises and kills are at least more visible than the commodified animals of intensive livestock production.

Fearnley-Whittingstall acknowledges his own weakness of will when it comes to being strict about food provenance and ethics, finally, but is nonetheless "looking for certain guarantees in the food [he] buy[s], beyond the simple matter of taste: 
guarantees of purity, sustainability, and transparency and openness on the part of the producer."(2001:29) Like Ottolenghi, he acknowledges that food is a great personal and social pleasure and should be enjoyed and relished, but FearnleyWhittingstall is much more deeply concerned about where our food is coming from, and just what is happening along the way.

Unlike all the other celebrity chefs surveyed, only these two acknowledged that our hedonistic and aesthetic pleasures need to be triangulated, somehow, with, among other things, the demands of animal (and environmental) ethics. Alongside the vegan chefs in our index - who are likely to score well both definitionally and as an artifact of the research design -Ottolenghi and Fearnley-Whittingstall provide potential models to adopt when it comes to minimizing the harms our food choices cause to animals.

\section{Conclusion}

This paper measured and analyzed the ethical implications of celebrity chef food recommendations. We focused on calculating the minimal required number of sentient animals that would have to be killed to create a given collection of recipes.

Several chefs who did well in our index did so without deliberately striving to reduce their animal harm footprints. In at least one case (that of de Laurentiis) this was the by-product of a generally sparing approach to cooking that called for smaller rather than larger amounts of food to be cooked and eaten. Conversely, chefs who did poorly frequently exhibited a highly hedonistic approach to food. This outcome suggests that frugal approaches to cooking and eating, particularly when they are informed by an awareness of animal carcass sizes, may be a meaningful first step omnivores can take to reduce their dietary harm footprints. So far as our index is concerned, books by Batali and other level-four chefs are vastly 
inferior to low scoring level-two chefs such as de Laurentiis, while the level-one chefs were ethically best of all.

A major, perhaps the primary reason omnivorous books can differ so radically in the average number of animals they kill is that the lives of food animals are widely regarded as too insignificant to warrant counting. Thus has it long been the norm, for example, not to require cameras in slaughterhouses. Similarly, the photography in cookbooks lavishly showcases the food, but rarely the animals from the which the food is made, and at this point in time, at least, it is absolutely unheard of for cookbooks to come with labelling that indicates how many animal lives their recipes require. By looking at the narratives of these books and indexing the number of animal lives that must be lost to follow the culinary recommendations of some of the world's most influential chefs, we hope to have taken a small step toward rendering the fate of food animals more visible.

\section{Bibliography}

Abeyesinghe S., Nicol, C., Hartnell, S. and Mathes, M. 2005. Can domestic fowl, Gallus gallus domesticus, show self-control? Animal Behavior 70: 1-11.

American Society for the Prevention of Cruelty to Animals (ASPCA) (2017). Farm animal confinement bans by state. http:/ / www.aspca.org/animalprotection/public-policy/farm-animal-confinement-bans. Accessed 16 March 2017.

Anderson, Roland C., Jennifer A. Mather, Mathieu Q. Monette, and Stephanie R.M. Zimsen. Octopuses (Enteroctopus dofleini) recognize individual humans. Journal of Applied Animal Welfare Science 13.3: 261-272.

Andreou, Alex. "Jamie Oliver, you haven't tasted real poverty. Cut out the tutting." The Guardian, opinion, August 27 2013. Available at:

https: / / www.theguardian.com/commentisfree/2013/aug/27/jamie-oliverpoverty-ready-meals-tv

Bagnoli, Carlo, Gian Paolo Lazzer, Francesca Setiffi, "Restaurants in the Age of Food Television," Micro \& Macro Marketing 3 (2016): 379-396. 
Batali, Mario. 2005. Molto Italiano: 327 simple Italian recipes to cook at home. New York: Ecco.

Batali, Mario. 2010. Molto gusto: easy Italian cooking. New York: HarperCollins Publishers.

Bayless, Rick. 2005. Mexican everyday. New York: W.W. Norton \& Company.

BBC News. 2010. Jamie Oliver's 30-Minute Meals breaks sales record. BBC News Online. www.bbc.co.uk/news/uk-11957627. Accessed March 15, 2017.

Berger, John. 1980. Why look at animals? In About Looking. New York: Pantheon Books.

Bourdain, Anthony. 2000. Kitchen confidential: adventures in the culinary underbelly. New York: Bloomsbury.

Bourdain, Anthony. 2004. Les Halles Cookbook: Strategies, Recipes, and Techniques of Classic Bistro Cooking. New York: Bloomsbury.

Bowater, Donna and Patrick Foster. "Fresh food champion Jamie Oliver signs frozen meals deal with Brazilian chicken giant," The Telegraph, July 23 2016, available at: http:/ / www.telegraph.co.uk/news/2016/07/24/fresh-foodchampion-jamie-oliver-signs-frozen-meals-deal-with-br /

Braithwaite Victoria. and Boulcott Philip. 2008. Can fish suffer? In Fish welfare ed. Edward Branson. Blackwell, Oxford: 78-92.

Brown, Culum, Jens Krause, and Kevin Laland. 2011. Fish cognition and behavior, 2nd Edition. Chichester, West Sussex: Wiley-Blackwell.

Brown, Culum. 2015. Fish intelligence, sentience and ethics. Animal cognition 18.1: $1-17$.

Broadcasters' Audience Research Board. 2017. Weekly top 30 programmes. BARB.

Buford, Bill. 2007. The Taming of The Chef. The New Yorker, April 2.

Buscimi, Francesco. The carnivorous mission of the celebrity chef. Critical Perspectives on Veganism. London: Palgrave Macmillan: 331-48.

Caraher, Martin, Tim Lange and Paul Dixon. 2006. The influence of TV and celebrity chefs on public attitudes and behavior among the English public. Journal for the Study of Food and Society 4: 27-46.

Chandroo, Kris, Ian Duncan, and Richard Moccia. 2004. Can fish suffer?: perspectives on sentience, pain, fear and stress. Applied Animal Behaviour Science 86: 225-250. 
Chicago Tribune. April 25, 2016. 10 years ago: Chicago's fois gras fiasco. Available at http:/ / www.chicagotribune.com/news/ plus/ ct-chicago-foie-grasban-anniversary-20160424-story.html. Accessed March 21, 2017.

Colicchio, Tom. 2003. The Craft of Cooking. New York: Clarkson Potter.

Dagevos, Hans. 2016. Exploring flexitarianism: meat reduction in a meat-centred food culture. In Impact of meat consumption on health and environmental sustainability. Talia Raphaely and Dora Marinova, eds. Hershey, Pa.: IGI Global: $233-43$.

Deen, Paula. 1998. The lady \& sons savannah country cookbook. New York: Random House.

Dixler, Hillary. 2015. The decade-long foie gras fight, explained. Eater. Available at http: / / www.eater.com/2015/1/9/7513743/foie-gras-ban-california-historyappeal-peta-aldf. Accessed 16 March 2017.

Druce, Clare and Philip Lymbery. 2008. Outlawed in Europe. In In defense of animals: the second wave. ed. Peter Singer: 123-131. Malden: Blackwell.

Drummond, Ree. 2009. The pioneer woman cooks: recipes from an accidental country girl. New York: William Morrow Cookbooks.

Eisnitz, Gail. 1997. Slaughterhouse: The Shocking Story of Greed, Neglect and Inhuman Treatment Inside the U.S. Meat Industry. Amhert, NY: Prometheus.

Fearnley-Whittingstall, Hugh. 2001. The river cottage cookbook. London: HarperCollins.

Fearnley-Whittingstall, Hugh. 2011. River cottage veg. Berkeley: Ten Speed Press.

Fieri, Guy and Ann Volkwein. Guy fieri food: Cookin' it, livin' it, livin' it. (2011). New York: William Morrow.

Fiore, Toni. 2008. Totally vegetarian: easy, fast, comforting cooking for every kind of vegetarian. Boston: Da Capo Lifelong Books.

Food and Wine (2010). Team Mario Batali's Vegetable Challenge. Food and Wine. Available at http:/ / www.foodandwine.com/articles/team-mario-batalisvegetable-challenge. Accessed March 20, 2017.

Garten, Ina. 1999. The barefoot contessa cookbook. New York: Clarkson Potter.

Godfrey-Smith, Peter. 2013. Cephalopods and the evolution of the mind. Pacific Conservation Biology 19.1: 4-9. 
Godfrey-Smith, Peter. Other minds: the octopus, the sea and the deep origins of consciousness. Farrar, Straus and Giroux, 2016.

Gregory, N.G. (1998). Animal Welfare and Meat Science. New York: Cabi Publishing.

Henderson, Jeff. 2008. Chef Jeff cooks: in the kitchen with America's inspirational new culinary star. New York: Scribner.

Henderson, Joan. 2011. Celebrity chefs: expanding empires. British Food Journal 113.5:613-624.

Humane Society International. 2015. India Foie Gras Import Ban Applauded. Hsi.org. http:/ / www.hsi.org/world/india/news / releases / 2014/07/india-foiegras-import-ban070714.html? Accessed March 162017.

Holland, Rob, Dwight Loveday, and Kevin Ferguson 2014. How Much Meat to Expect from a Beef Carcass. University of Tennessee Institute of Agriculture, PB 1822. https: / / extension.tennessee.edu/publications/

Documents/PB1822.pdf. Accessed May 7, 2017.

"How Much Meat?" Oklahoma Department of Agriculture, Food, \& Forestry. Food Safety Division: Meat Inspection Services. Available at: https:/ / www.oda.state.ok.us/food/ fs-cowweight.pdf. Accessed May 7, 2017.

Hoffmeyer, Jesper. Biosemiotics: An Examination into the signs of life and the life of signs. Trans. Jesper Hoffmeyer and Donald Favareau. Ed. D. Favareau. University of Chicago Press, 2008.

Human Society of the United States (2008). The welfare of animals in the aquaculture industry. http:/ / www.humanesociety.org/assets/pdfs / farm/ hsus-the-welfare-of-animals-in-the-aquaculture-industry-1.pdf. Accessed May 18, 2017.

Hvorecny, Lauren, Jessica Grudowski, Carrie Blakeslee, Tiffany Simmons, Paula Roy, Jennifer Brooks, Rachel Hanner et al. 2007. Octopuses (Octopus bimaculoides) and cuttlefishes (Sepia pharaonis, S. officinalis) can conditionally discriminate. Animal cognition 10.4: 449-459.

Howard, Simon, Jean Adams, and Martin White. 2012. Nutritional content of supermarket ready meals and recipes by television chefs in the United Kingdom: cross sectional study. BMJ 345: e7607.

Hsu, Hua. "The accidental American genius of Guy Fieri," The New Yorker, July 5, 2016.

Hyman, Gwen. "The taste of fame: Chefs, diners, celebrity, class." Gastronomica 8.3 (2008): 43-52. 
Italie, Leanne. "Chef Paula Deen hid diabetes, pushed high-fat food," San Diego Union-Tribune, Jan 17 2012, available at:

http:/ / www.sandiegouniontribune.com/sdut-chef-paula-deen-hid-diabetespushed-high-fat-food-2012jan17-story.html

Jarvis, Erich, Onur Güntürkün, Laura Bruce, Andras Csillag, Harvey Karten, Wayne Kuenzel, Lorena Medina et al. 2005. Avian brains and a new understanding of vertebrate brain evolution. Nature Reviews Neuroscience 6: 151-159.

Johnston, Josée, Alexandra Rodney, and Phillipa Chong. 2014. Making change in the kitchen? A study of celebrity cookbooks, culinary personas, and inequality. Poetics 47: 1-22.

Jones, Marc. 2009. A celebrity chef goes global: the business of eating." Journal of Business Strategy 30.5:14-23.

Kaplan Gisela and Rogers Lesley. (2005). “Bird Brain? It may be a Compliment!” Cerebrum 7/3: 1.

Kuba, Michael Ruth Byrne, Daniela Meisel, and Jennifer Mather. 2006. When do octopuses play? Effects of repeated testing, object type, age, and food deprivation on object play in Octopus vulgaris. Journal of comparative psychology 120.3: 184.

Lagasse, Emeril and Jessie Tirsch. 1993. Emeril's new New Orleans cooking. New York: William Morrow and Company, Inc.

Lakshmi, Padma. 2007. Tangy tart hot $\mathcal{E}$ sweet: a world of recipes for every day. New York: Weinstein Books.

Laland, Keven, Culum Brown, and Jens Krause. 2003. Learning in fishes: from three-second memory to culture. Fish and Fisheries 4: 199-202.

Lambooij, E., J.W. Van de Vis, R.J Kloosterboer and C. Pieterse. 2002a. Welfare aspects of live chilling and freezing of farmed eel (Anguilla anguilla L.): neurological and behavioural assessment. Aquaculture, 210: 159-169.

Lambooij, E., J.W. Van De Vis, H. Kuhlmann, W. Münkner, J. Oehlenschläger, R. J. Kloosterboer and C. Pieterse. 2002b. A feasible method for humane slaughter of eel (Anguilla anguilla L.): electrical stunning in fresh water prior to gutting. Aquaculture Research 33: 643-652.

Lamey, Andy. 2012. Primitive self-consciousness and avian cognition. The Monist 95: 486-510.

Lane, Samantha and Stephanie Fisher. 2015. The influence of celebrity chefs on a student population." British Food Journal 117.2: 614-628.

Laurentis, Giada de. 2005. Everyday Italian: 125 simple and delicious recipes. New York: Clarkson Potter. 
Lawson, Nigella. 2007. Nigella express: good food, fast. New York: Hyperion.

Lee, Susur. 2015. Susur - a culinary life. Berkeley: Ten Speed Press.

Marino, Lori. 2017. Thinking chickens: a review of cognition, emotion, and behavior in the domestic chicken. Animal Cognition 20: 127-47.

Marti, Daniel L., Rachel J. Johnson, and Kenneth H. Mathews Jr. 2012. Where's the (not) meat? Byproducts from beef and pork production. Journal of Current Issues in Globalization 5.4: 397.

Mather, Jennifer A. 2008. Cephalopod consciousness: behavioural evidence. Consciousness and cognition 17.1: 37-48.

Matwick, Lelsi, and Keri Matwick. "Cooking at home: A multimodal narrative analysis of the Food Network." Discourse, Context \& Media 17 (2017): 20-29.

McEwan, Mark. 2010. Great food at home: family-style recipes for everyday. City: Viking.

McMahan, Jeff. 2002. The ethics of killing: problems at the margins of life. New York: Oxford University Press.

McMahan, Jeff. 2008. Eating animals the nice way. Daedalus Winter: 1-11.

Mood, Alison. 2010. Worse things happen at sea: the welfare of wild-caught fish. Fishcount.org.uk. Accessed May 18, 2017.

National Oceanic and Atmospheric Administration (2012). Basic questions about aquaculture. http:/ / www.nmfs.noaa.gov/aquaculture/faqs/faq_aq_ 101.html. Accessed May 18, 2017.

National Turkey Federation. 2017. Purchasing turkey: yield from turkey. http:/ / www.eatturkey.com/foodsrv/manual/purch6. Accessed May 15, 2017.

Nordgreen, Janicke, Joseph Garner, Andrew Janczak, Birgit Ranheim, William Muir, and Tor Einar Horsberg. 2009. Thermonociception in fish: effects of two different doses of morphine on thermal threshold and post-test behaviour in goldfish (carassius auratus). Applied Animal Behaviour Science 119:101-107.

Nussbaum, Martha. 2006. Frontiers of justice: Disability, nationality, species membership. Cambridge: Harvard University Press.

Oklahoma Department of Agriculture Food an Forestry. 2017a. How Much Meat? (Pig) http: / / www.oda.state.ok.us / food/fs-hogweight.pdf. Accessed March 21, 2017. 
Oklahoma Department of Agriculture Food an Forestry. 2017b. How Much Meat? (Cow) https: / / www.oda.state.ok.us/food/ fs-cowweight.pdf. Accessed March 21, 2017.

Oliver, Jamie. 2010. Jamie's 30-minute meals. London: Penguin Books.

Ottolenghi, Yotam. 2010. Plenty: vibrant vegetable recipes from London's Ottolenghi. San Francisco. Chronicle Books.

Ottolenghi, Yotam. and Samir Tamimi. 2013. Ottolenghi: the Cookbook. Berkeley: Ten Speed Press.

Pachirat, Timothy. Every Twelve Seconds: Industrialized Slaughter and the Politics of Sight. Yale University Press, 2011.

Penders, B. (2012). Re Nutritional content of supermarket ready meals and recipes by television chefs in the United Kingdom: cross sectional study. BMJ 345:e7607.

Powell, Helen, and Sylvie Prasad. "' As Seen on TV." The celebrity expert: how taste is shaped by lifestyle media." Cultural Politics 6.1 (2010): 111-124.

Plumwood, Val. The Eye of the Crocodile. ANU E Press, 2012.

Puck, Wolfgang. 2004. Wolfgang Puck makes it easy: delicious recipes for your home kitchen. Nashville: Thomas Nelson.

Ramsay, Gordon. 2007. Fast food: recipes from the F Word. London: Quadrille Publishing.

Raines, Christopher. 1999. The butcher kept your meat? Penn State Meat Science. http: / / animalscience.psu.edu/ extension/meat/pdf/The\%20Butcher $\% 20$ Stole $\% 2$ 0My\%20Meat.pdf. Accessed May 7, 2017.

Ray, Rachael. 2001. Veggie meals: Rachael Ray's 30-Minute Meals. New York: Lake Island Press.

Ray, Rachael. 2005. 365: no repeats: a year of deliciously different dinners. New York: Clarkson Potter.

Redden, Guy. "Misterchef? Cooks, Chefs and Gender in MasterChef Australia." Open Cultural Studies 1.1 (2017): 125-139.

Regolin, Lucia, Rosa Rugani, Piero Pagni, and Giorgio Vallortigara. 2005. Delayed search for social and nonsocial goals by young domestic chicks, Gallus gallus domesticus. Animal Behaviour, 70.4: 855-64. 
Rogers Lesley and Gisela Kaplan. 2004. Preface. , Iin Comparative vertebrate cognition: are primates superior to non-primates?, eds. Lesley Rogers and Gisela Kaplan eds., New York: Kluwer Academic.

Romero, Terry, Toni Fiore, and Miyoko Schinner. 2015. Vegan mashup: Season 2 cookbook. Kent, Ohio: All Art Media.

Salkin, Allen. 2013. From scratch: inside the food network. New York: J. P. Putnam.

Salman, J., P. Vannier, P. and M. Wierup. 2009. Species-specific welfare aspects of the main systems of stunning and killing of farmed eels (Anguilla anguilla) Scientific Opinion of the Panel on Animal Health and Welfare. The ESFA Journal 1014: 1-42.

Samuelsson, Marcus. 2014. Marcus off duty: the recipes I cook at home. Boston: Houghton Mifflin Harcourt.

Scholes, Lucy. "A slave to the stove? The TV celebrity chef abandons the kitchen: lifestyle TV, domesticity and gender." Critical Quarterly 53:3 (2011): 44-59.

Self, Will. "Why I hate Jamie Oliver," New Statesman, Oct 31 2013, available at: https: / / www.newstatesman.com/2013/10/triceratops-and-cowpoke-live-piousharmony-new-outpost-jamie-olivers-army

Singer. Peter. 1990. Animal liberation. Second Edition. New York: New York Review of Books.

Singer, Peter. 2010. Fish: the forgotten victims on our plate. The Guardian, September 14.

Sneddon, Lynne. 2003. The evidence for pain in fish: the use of morphine as an analgesic. Applied Animal Behaviour Science 83: 153-162.

Sneddon, Lynne. 2007. Assessing pain perception in fish from physiology to behaviour. Comparative Biochemistry and Physiology Part A: Molecular \& Integrative Physiology 146: S78.

Sneddon, Lynne, Victoria Braithwaite, and Michael Gentle. 2003. Do fishes have nociceptors? evidence for the evolution of a vertebrate sensory system.

Proceedings of the Royal Society B Biological Sciences 270: 1115-1121.

Sneddon, Lynne and Matthew Leach. 2016. Anthropomorphic denial of fish pain. Animal Sentience 3 (28): 1.

Spence, Des. "Jamie's school dinners" (TV review), in BMJ 330 (2005): 678.

Springmann, Marco, Daniel Mason-D'Croz, Sherman Robinson, Keith Wiebe, H. Charles Godfray, Mike Rayner, and Peter Scarborough. 2016. Mitigation 
potential and global health impacts from emissions pricing of food commodities. Nature Climate Change 7: 69-74.

Stone, Curtis. 2013. What's for dinner: delicious recipes for a busy life. New York: Ballantine Books.

Taylor, Pollyanna, Marie Haskell, Michael Appleby, and Natalie Waran. 2002. Perception of time duration by domestic hens. Applied Animal Behavior Science. 76.1: 41-51.

Telegraph Food. 2015. Jamie Oliver goes veggie: six things we learnt about the chef. The Telegraph, 13 May.

Theodore, Laura. (2011). Jazzy Vegetarian: Lively Vegan Cuisine That's Easy and Delicious. Summertown, TN: Book Publishing Company.

Tye, Michael. 2017. Tense Bees and Shell-shocked Crabs: Are Animals Conscious?

Oxford: Oxford University Press.

Uexküll, Jakob von. 2013. A Foray into the Worlds of Animals and Humans, Minneapolis: University of Minnesota Press.

Varner, Gary. 1998. In Nature's Interests? Interests, Animal Rights and Environmental Ethics. Oxford: Oxford University Press.

Weatherby. Taylor. 2016. Anthony Bourdain Splits From Wife Of 9 Years Celebrity Chef Getting Divorced.

http: / / hollywoodlife.com/2016/09/19/anthony-bourdain-divorce-wife-ottaviabusia-ending-marriage-split/. Accessed 15 March 2017.

Wells, Pete. 2012. As Not Seen on TV. The New York Times. November 13.

Wilson, Jonathan. 2013. Stress Physiology. Eel Physiology. Francesca Trischitta, Yoshio Takei and Philippe Sébert, eds. (Boca Raton, FL: CRC Press): 318-358. 